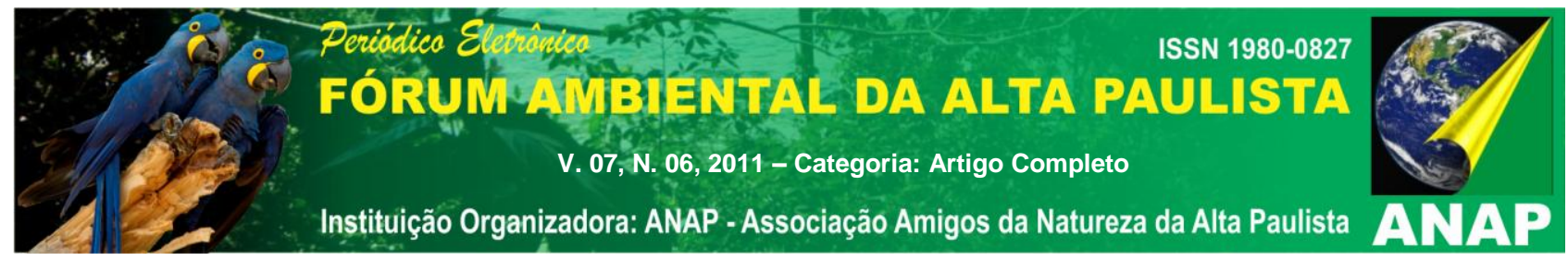

\title{
EDUCAÇÃO AMBIENTAL NOS AMBIENTES NATURAIS DO ESTADO DE SÃO PAULO
}

\author{
Paulo Henrique Peira Ruffino ${ }^{1}$ \\ Mayla Willik Valenti ${ }^{2}$ \\ Matheus Gonçalves dos Reis ${ }^{2}$
}

Carolline Zatta Fieker ${ }^{3}$

\begin{abstract}
RESUMO: O presente ensaio busca, por meio de analise de literatura das áreas ambientais, refletir sobre a interpretação e utilização dos instrumentos legais do que se denomina educação ambiental (EA) no Brasil e ambientes naturais nas paisagens do Estado de São Paulo. Apresenta como base conceitual de estabelecimento de processos de EA a referência Conceitos para se fazer Educação Ambiental, e, como método de intervenção os Princípios e Objetivos da Educação Ambiental para os ambientes paulistas que, neste momento são apresentados por meio de levantamentos do Sistema de Informações Florestais do Estado de São Paulo e pela configuração das Áreas Protegidas e Unidades de Conservação gerenciadas pelo Sistema Estadual de Florestas.
\end{abstract}

Palavras chave: Educação ambiental, ambientes naturais, Estado de São Paulo.

\section{1 - INTRODUÇÃO}

O processo da educação ambiental (EA) segundo legislação brasileira específica (Lei 9.795 de 1999 que cria a Política Nacional de Educação Ambiental - PNEA) deve se dar em todos os níveis e modalidades de educação seja no âmbito da educação formal

\footnotetext{
${ }^{1}$ Pesquisador Científico - Manejo de Áreas Naturais / Educação Ambiental - Instituto Florestal / Secretaria do Meio Ambiente do Estado de São Paulo phruffino@if.sp.gov.br

${ }^{2}$ Doutorand@s do Programa de Pós-Graduação em Ecologia e Recursos Naturais da Universidade Federal de São Carlosmaylabio@yahoo.com.br, matheus.reis@gmail.com

${ }_{3}^{3}$ Mestranda do Programa de Pós-Graduação em Ecologia e Recursos Naturais da Universidade Federal de São Carlos carolfieker@gmail.com
} 


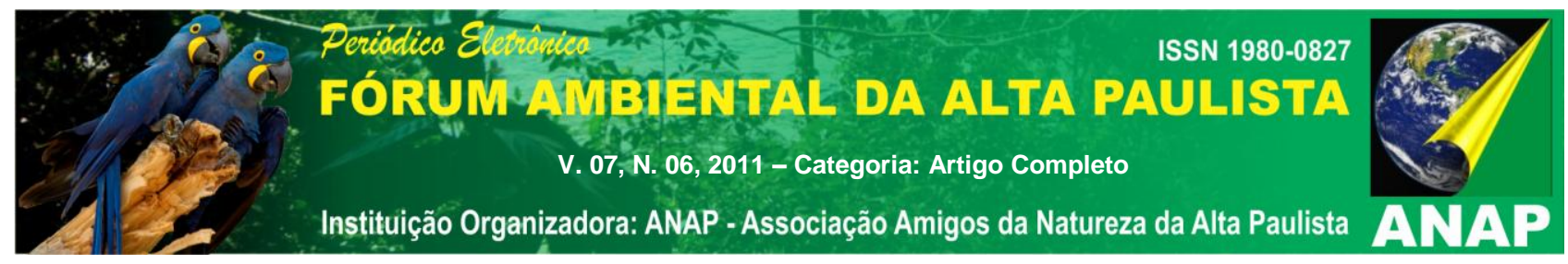

seja no âmbito da educação não formal se baseando, entre outros princípios , na preocupação de garantir:

II - a concepção do meio ambiente em sua totalidade, considerando a interdependência entre o meio natural, o sócio econômico e o cultural, sob o enfoque da sustentabilidade;

Pois bem, não é difícil notar que a grande ênfase dada em programas formais e não formais de EA esteja baseada em problemas ambientais cotidianos como falta de água potável, resíduos sólidos, saneamento básico e outros vieses da vida essencialmente urbana na qual vivem hoje $80 \%$ da população brasileira. Esta recorrente situação de procura por soluções ambientais, econômicas, sociais e culturais pragmáticas via EA além de ocultar outras possibilidades de ação da sociedade, às vezes acaba por sombrear reais problemas de ordem ambiental que não estão tão evidentes, vistos do prisma urbano. Afinal, a maneira como se percebe e interpreta os diferentes ambientes naturais e/ou urbanos, bem como ações desempenhadas neles, são reflexos diretos das experiências vividas nestes mesmos espaços (ITTELSON, 1978)

A perda diária de biodiversidade, o desequilíbrio climático global e a escassez de recursos e belezas naturais tem-nos infligido pesado fardo que, aos olhos de muitos parece ser erroneamente algo para as décadas futuras apenas. É notório e urgente, portanto, a necessidade de interpretar e desenvolver novas percepções que incorporem à concepção do meio em sua totalidade como já previsto no princípio da Política Nacional de Educação Ambiental.

Pode-se considerar a totalidade dos ambientes hoje como três espaços diferentemente manejados, interpretados e reconhecidos sócio-político e economicamente que são:

1- ambientes urbanos - toda a configuração onde estão sediadas fisicamente as plantas político-administrativas, comerciais, econômicas, de saneamento, sociais e educacionais da maior parte dos municípios brasileiros, em alguns casos como o municípios de Americana e Águas de São Pedro, a área urbana abrange quase que a totalidade do município. Nestes ambientes a população residente e ou usuária faz uso intensivo dos recursos naturais já manufaturados (em geral distante das fontes produtoras), devido a baixa percepção sobre possíveis impactos destas ações no ambiente como um todo ou à falta de acesso a outras formas de consumo. Nesses espaços é comum o uso e descarte de da água sem 


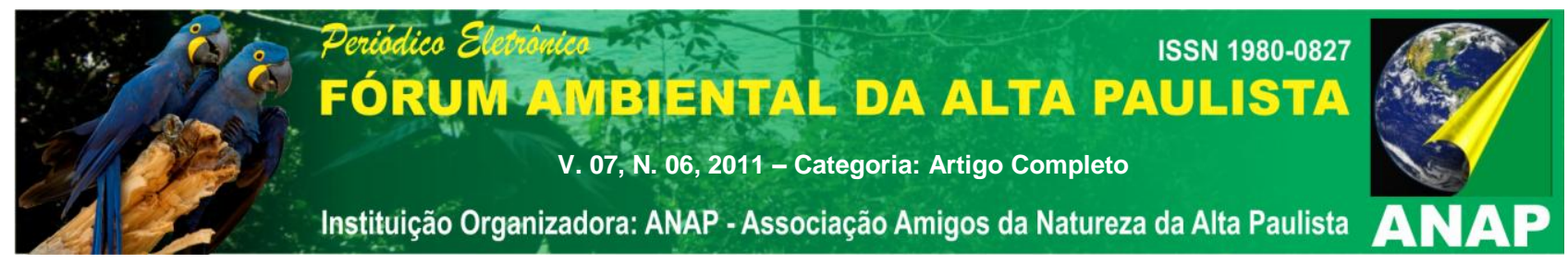

planejamento; o consumo excessivo, produção excedente e descarte inadequado de materiais sólidos; o uso inadequado de energia; a falta de valorização de espaços vegetados; a realização de alterações no relevo (rede hídrica) e das paisagens naturais. Esses são exemplos do distanciamento da vida urbana em relação à dinâmica natural e seus limites de recursos que, de acordo com Ittelsen (1978), pode implicar em não reconhecimento de alguns elementos do meio distanciado, e posteriormente pela percepção distorcida ou estereotipada, resultar em ações danosas a estes espaços;

2- ambientes rurais - toda a extensão de áreas não urbanizadas e/ou construídas que sediam as economias agrícolas (alimentos, matérias primas para economias diversas, turismo diversos, e etc.). Esses ambientes apresentam baixo adensamento demográfico, sendo que no Brasil menos de $20 \%$ da população reside nas áreas rurais. Nesses espaços o uso dos recursos naturais se faz tanto para a manutenção direta das populações (água, alimentos, energia) quanto para o fornecimento de produtos para o mercado. A percepção destes espaços e seus limites de uso pelas populações residentes e usuárias é culturalmente afetado pela dimensão histórica dos ambientes rurais e respectiva política de latifúndio impregnada na sociedade brasileira. Um bom referencial para este entendimento é a atual crise política sobre as propostas de alteração do Código Florestal brasileiro. Não há consenso geral sobre os reais serviços ambientais prestados pelos ambientes pouco manejados (áreas naturais e ou agricultura familiar, orgânica, biodinâmica, etc.); e

3- ambientes naturais - extensões em áreas urbanas e ou rurais que apresentam características ambientais dos biomas originais da área. Quando existentes, as populações destes espaços são regulamentadas e cumprem normas específicas sobre o uso dos recursos. É muito comum haver conflitos entre estas populações quando estes espaços são protegidos em formas de Unidades de Conservação,

O entendimento sócio-político e ambiental destes três espaços e suas interações como região, país, continente e planeta é a base e ao mesmo tempo o objetivo da elaboração de processos de EA que, buscarão contemplar e enfatizar em cada população/ambiente suas vocações e limitações. O que se propõe com este ensaio é 


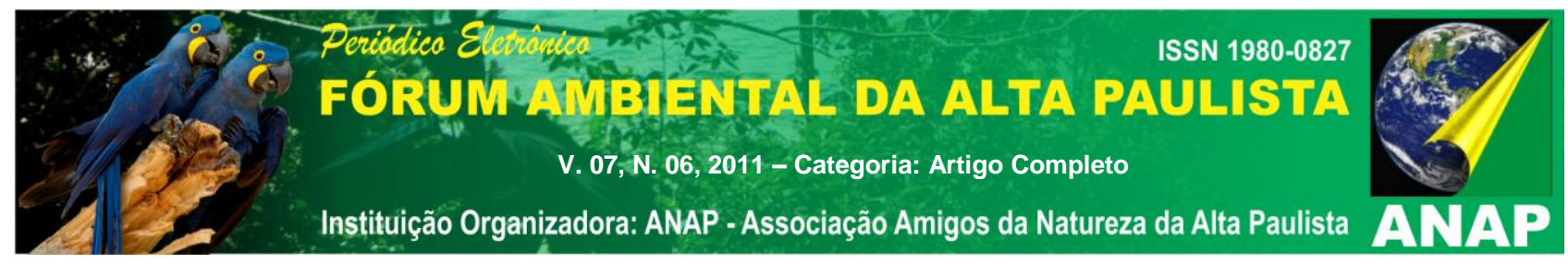

refletir as bases teóricas e técnicas, seja em âmbito legal, seja em âmbito estrutural de políticas públicas de educação ambiental, de ambientes naturais e de conservação de áreas com ênfase na atual situação ambiental paulista para fins de desenvolvimento dos processos de educação ambiental.

\section{2 - DESENVOLVIMENTO}

2.1 - Os Conceitos, Princípios e Objetivos da Educação Ambiental.

No ano de 1989 a UNESCO encomendou uma publicação denominada de Harvesting one hundredfold - Key concepts and case studies in Enviromental Education (MEADOWS, 1989) que, teve alguns de seus capítulos traduzidos para o português sob a denominação de Conceitos para se Fazer Educação Ambiental (SÃO PAULO, 1999). Tratou-se de uma consulta internacional onde educadoras/es apresentaram e defenderam oito conceitos fundamentais para o desenvolvimento do processo de EA que são: níveis de ser, ciclos, sistemas complexos, crescimento populacional e capacidade de suporte, desenvolvimento ecologicamente sustentável, desenvolvimento socialmente sustentável, conhecimento e incerteza e sacralização.

Para a presente discussão vamos nos ater ao conceito de "níveis de ser" que, dentre outras reflexões, nos lembra que cada nível do planeta, seja ele físico (meio abiótico), biológico (biótico), humano (aqui destacado pela complexidade de relações e respectivos reflexos aos outros níveis), são geridos pelas leis da natureza em ordem crescente de grandeza.

O meio físico é composto pelos recursos minerais sólidos (rochas e solos), líquidos (água) e gasosos (atmosfera), que são regidos pelas leis da física e da química.

O meio biológico é composto por todos os seres vivos (animais, vegetais e microrganismos) que dependem diretamente do meio físico sendo, portanto, regidos pelas leis da física, química e também pelas leis biológicas. Os seres humanos também fazem parte desse meio, porém, devido às suas características particulares e sua importância para a educação ambiental, será tratado separadamente.

O meio humano, também chamado de tecnosfera ou sociosfera, é composto pelos seres humanos e suas configurações sociais, estruturais e culturais e, como as anteriores, 


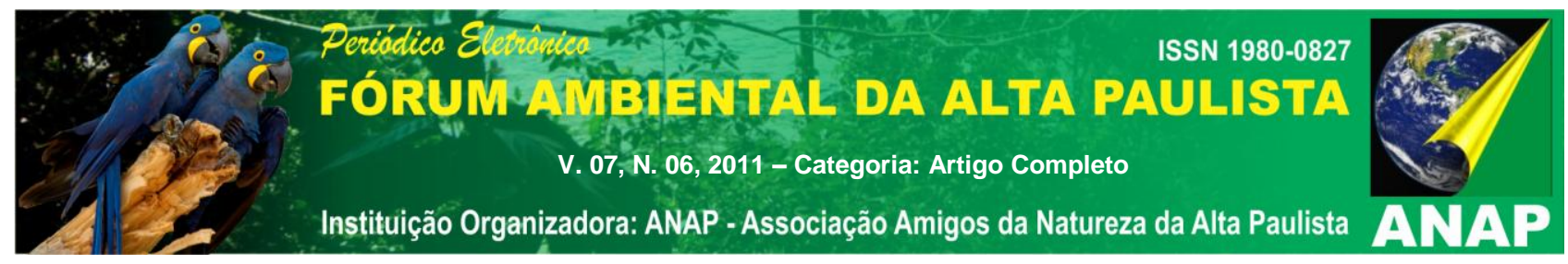

é regido igualmente e na mesma ordem de grandeza pelas leis anteriores, somadas às próprias leis humanas.

A questão que se coloca diz respeito ao distanciamento que o meio humano toma dos demais meios colocando-se em situação crítica de sobrevivência enquanto nível sem, no entanto, os indivíduos sentirem esta condição limiar. Tais são as reservas planetárias de energia e demais riquezas e tais são as desigualdades entre os povos que, ao que parece, faz com que os limites deste exaurimento cheguem a passos lentos ao conhecimento das sociedades. Mas, independente da velocidade com que os desequilíbrios ocorrem, a necessária re-compreensão dos níveis e de suas dinâmicas pode ser feita a partir de ações educativas em ambientes naturais, quando estes são tratados em sua complexidade. A EA nos ambientes naturais passa, então, a requerer objetivos e métodos que vislumbrem a totalidade do ambiente por meio de seus próprios limites segundo as leis de cada nível envolvido. Adotando-se os princípios e objetivos da EA apresentados por Smith apud Sato (1997), tem-se que o processo a ser iniciado proponha ações e reflexões de: sensibilização, compreensão, identificação das responsabilidades, desenvolvimento de competências e alcance da cidadania ambiental.

Estes princípios e objetivos aplicados às áreas naturais significam que:

- cada indivíduo se sensibilize que o planeta por si só foi auto-suficiente durante toda a existência do ser humano até os dias de hoje e que, somente a partir do do acelerado desenvolvimento tecnológico e do uso inconseqüente do mesmo,é que os indícios de desequilíbrios em escala global passam a afetar todo o sistema. Este sentimento de que ainda existem ambientes onde a vida acontece com baixa interfencia tecnológica humana, parece ser um grande passo a ser dado pela humanidade. Será que acreditamos que as árvores e os demais vegetais de uma floresta não precisam de adubos nem regas além do que o próprio ambiente lhes proporciona? E o que dizer dos animais? Quem alimenta um elefante ou um leão nos territórios da África? Quem alimenta a onça pintada, a anta ou o tamanduá nas áreas naturais do Brasil? E as próprias populações humanas nativas das Américas (povos indígenas), Africanas (tribos e grupos) e Australianas (aborígenes) que ainda se mantém em pequenos grupos isolados em áreas naturais espalhadas pelos continentes com pouco uso de instrumentos e recursos externos ao meio local? 


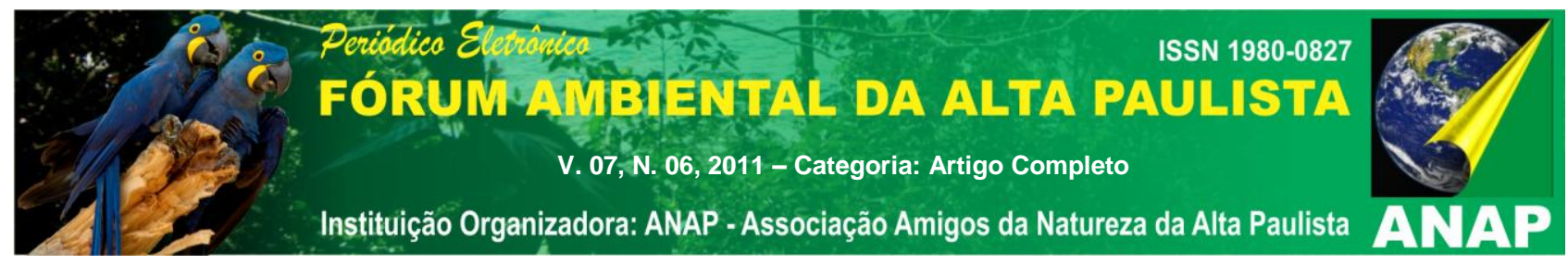

- cada indivíduo compreenda todas as leis que lhe dizem respeito, as leis da física, da química, da biologia, de cada sociedade e, em um futuro breve, quem sabe uma lei universal de respeito a todas as formas de vida. Esta etapa nos remete novamente aos estudos e compreensão da natureza e suas dinâmicas fundamentais de: como a energia flui nos sistemas, como os ciclos de água, de nutrientes e outros minerais se comportam, quais as relações entre os seres vivos e seus ambientes e quais as relações dos seres humanos entre si e com a natureza. A compreensão de que o ser humano é um animal nesta escala de relações e, como tal não pode se distanciar do todo, parece ser o grande desafio.

- cada indivíduo identifique as responsabilidades cabíveis a cada elemento do sistema e, em especial a cada segmento humano envolvido. Mesmo para as áreas naturais cabe o entendimento dos porquês da existência e conservação das mesmas, a quem cabe conservar e, qual o futuro desta enquanto espaço, isto é, está protegida de alguma maneira?

- cada indivíduo assuma posturas e atitudes, no que de fato lhe diz respeito, no que é de sua competência sobre estes espaços e sobre a conservação dos sistemas naturais. A ação resultante de um processo educativo deve ser realizada mediante este amplo processo reflexivo, sensitivo e de busca de responsabilidades para que haja a devida eficiência de ação e de duração, isto é, de verdadeira incorporação de valores para que a prática não seja vazia. Ações sobre, para e nas áreas naturais serão no sentido de manutenção, proteção (legal e física), manejo, recuperação/restauração e, em casos extremos, recuperação na totalidade, como é o caso de países europeus (Espanha, em especial).

A efetividade do processo da EA tanto para os ambientes naturais, quanto para qualquer outra motivação que seja realmente estrutural, como sugerido pela referência Conceitos para se fazer EA, alcança nos indivíduos concernidos o que se denomina de cidadania ambiental. Salienta-se, no entanto, que este ápice do processo não se assemelha com o conceito de clímax por jamais estabilizar visto que se trata de um empoderamento do coletivo humano com relação ao seu papel enquanto nível de ser no planeta. 


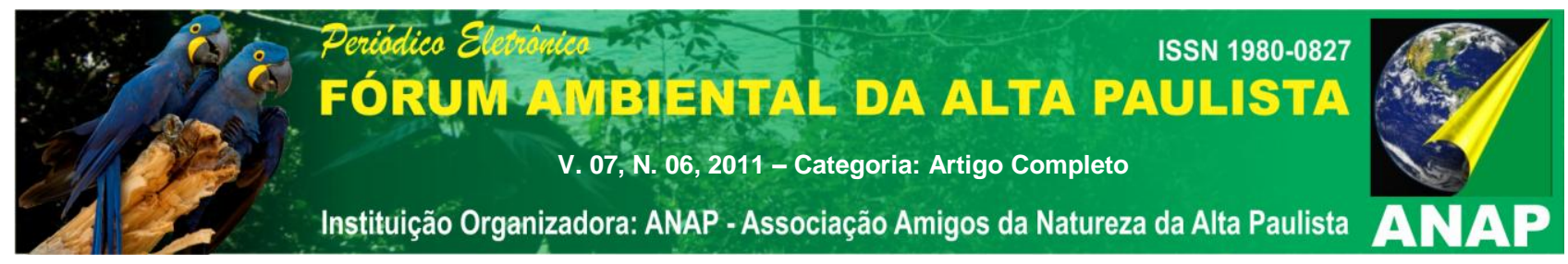

2.2 - Os Ambientes Naturais e as estruturas de conservação no Brasil.

Apresentaremos os ambientes naturais como espaços ainda existentes e, de alguma maneira protegidos pelo atual sistema legal brasileiro. Nesta perspectiva, os mesmos se efetivam como parte fundamental dos processos de EA necessários para a interpretação do ambiente em sua totalidade.

Em sendo o Brasil um país de extensão continental com expansão recente de fronteiras econômicas e políticas, vide, por exemplo, o Estado de São Paulo que até os idos de 1868 apresentava em sua cartografia a denominação de "Terrenos ocupados pelos indígenas ferozes" em toda sua extensão oeste, Figura 19 (ALMEIDA, 1968 in CAVENAGHI, 2006), os ambientes naturais ainda estão presentes em nossas paisagens ainda que de forma fragmentada ou, quando estes inexistem, de forma sentimental nas relações entre a geração que hoje se encontra na chamada terceira idade paulista.

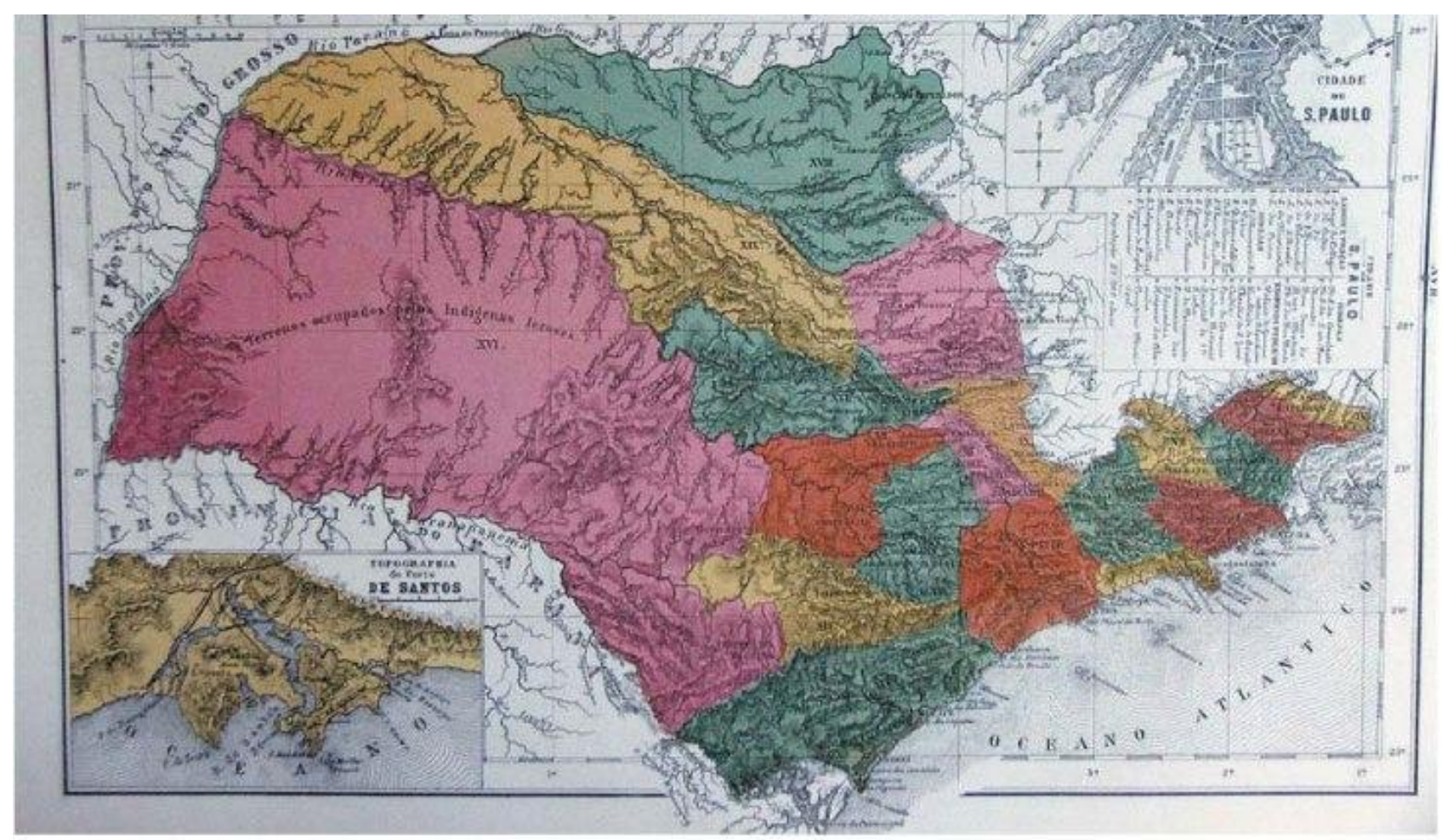

Figura 19 - Cândido Mendes de Almeida, Provincia de S. Paulo (ALMEIDA, 1868, p. XVIII). Acervo da Biblioteca da Faculdade de Filosofia, Letras e Ciências Humanas da Universidade de São Paulo, São Paulo.

Com esta característica de expansão recente, muito destes ambientes ainda existentes derivam de dois processos sócio-políticos e econômicos que são:

a) falta de tempo hábil ou de tecnologia para expansão das fronteiras; e ou 


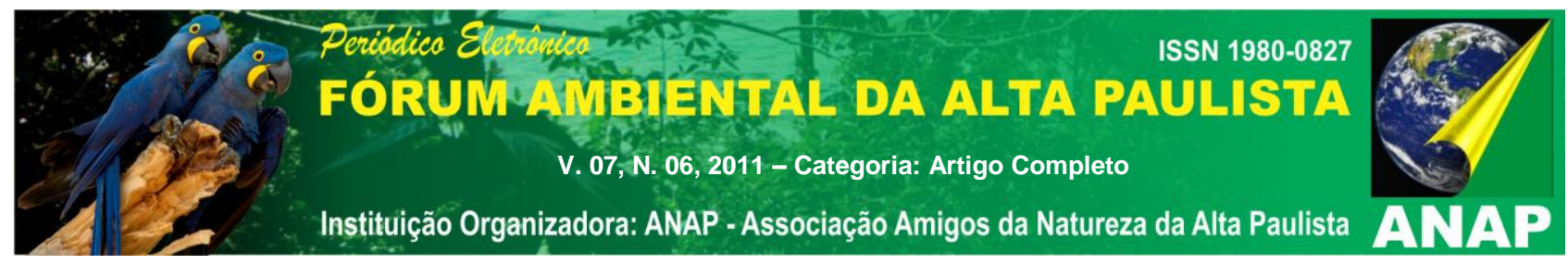

b) incidência das primeiras políticas de conservação ambiental que datam das décadas de 1930 (Código das Águas de 1934), década de 1960 (Código Florestal de 1965, de Caça e Pesca de 1967) no Brasil.

Assim, o panorama ambiental brasileiro nos apresenta ao mesmo tempo ambientes conservados via proteção legal voluntária (Unidades de Conservação) e proteção legal involuntária (Áreas de Preservação Permanente e Reservas Legais) e os ambientes ainda não explorados em sua totalidade que, pela legislação vigente são passíveis de serem utilizados, ao menos em partes.

Considerando que, independente do processo de proteção em que estejam inseridos os ambientes naturais, ainda falta à sociedade uma melhor compreensão sobre os benefícios da conservação ambiental e sobre o porquê dos mesmos possuírem tamanha importância no sentido da conservação biológica e no controle climático, o investimento em processos de sensibilização e compreensão para fins de ações proativas sobre estes ambientes são pertinentes e urgentes.

Para cada região do Brasil pode-se inferir uma estratégia de ação de acordo com o estado de conservação e porcentagem em área destes ambientes, pois, como citado, convivemos com espaços ainda conservados (regiões Norte e Centro Oeste) enquanto outros apresentam fronteiras já estabelecidas de expansão (regiões Sul e Sudeste).

Neste momento, nos atemos às características e atuais condições dos ambientes naturais paulistas, sejam eles protegidos voluntariamente, sejam eles protegidos pela força da lei ambiental. Consideramos que o Estado de São Paulo já atingiu o limite físico de suas fronteiras agrícolas pois, segundo os últimos inventários florestais, já apresenta aumento crescente de áreas nativas nas últimas duas décadas segundo dados do SIFESP 2010 apresentados na Tabela 1.

Tabela 1. Inventário Florestal da Vegetação Nativa do Estado de São Paulo (SIFESP 2010)

\begin{tabular}{lcc}
\hline Vegetação nativa & $1990 / 92$ & $2008 / 09$ \\
Área total - hectares & 3.330 .740 & 4.343 .000 \\
Porcentagem da área total do Estado & 13,43 & 17,51 \\
\hline
\end{tabular}




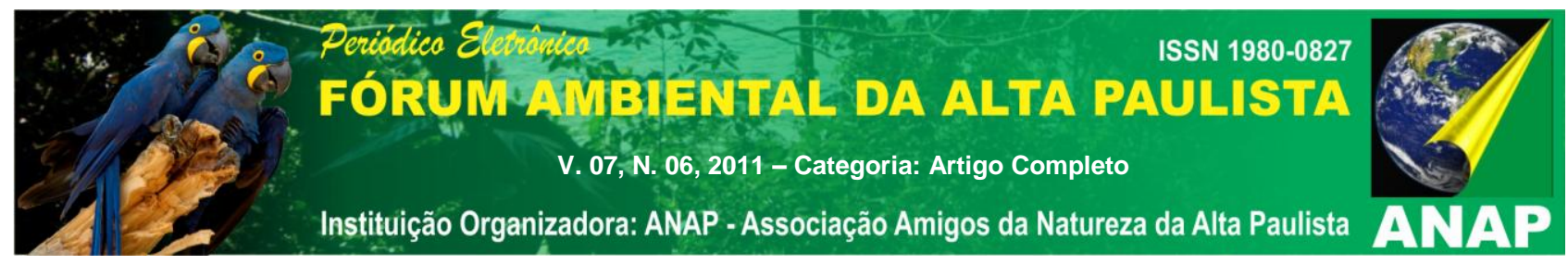

Observa-se que, segundo esta síntese, o Estado estabilizou os processos de ocupação de ambientes naturais e que, seja por ações de recuperação, criação de novas áreas protegidas ou mesmo por abandono, os mesmos apresentam crescimento representativo em área nas últimas duas décadas.

Estas áreas estão juridicamente fundamentadas em um dos seguintes instrumentos Legais:

- Código Florestal - Lei 4.771 de 1965 de que define dois tipos de áreas especialmente protegidas que são as Áreas de Preservação Permanente e as Reservas Legais;

- Sistema Nacional de Unidades de Conservação (SNUC) - Lei 9.985 de 2000 que classifica as áreas em dois grupos de proteção que são Unidades de Conservação de Proteção Integral e Unidades de Conservação de Uso Sustentável;

- Áreas de Reconhecimento Internacional - Reserva da Biosfera (Programa MaB, 1970 - Dec. 74685/74 e Dec.Pres. 21/09/99), Sítios Ramsar Convenção sobre Zonas Úmidas, 1971 promulgada pelo Dec. 1905/96) e Sítios do Patrimônio Mundial Natural (Convenção do Patrimônio Mundial, 1972 - promulgada pelo Dec. 80978/1977);

- Terras Indígenas - Lei 6.001 de 1973 que cria o Estatuto do Índio e regulariza a situação jurídica dos mesmos no território brasileiro.

\section{3 - O estabelecimento de Programas de EA nos Ambientes Naturais}

Um programa de EA nos moldes apresentados requer o pleno entendimento do espaço natural e seu contexto regional de conservação para ser elaborado. Requer escolha de público que tenha interação com este espaço e, por fim requer interesse político para que o público tenha meios de atuar concretamente sobre este espaço. Qualquer um dos requisitos que falte ou falhe, todo o processo pretendido será afetado e, os objetivos maiores da EA não serão alcançados.

No que diz respeito ao entendimento e contextualização do espaço em escala regional, tem-se que a identificação política e fundiária correta e uso atual e ou desejado do mesmo definirá a responsabilidade do programa. Por exemplo: 


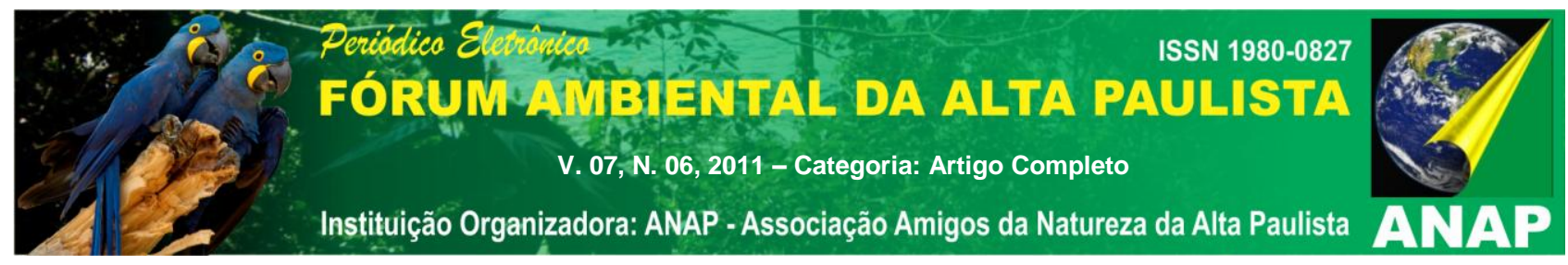

- em se tratando de espaços públicos naturais não previstos no SNUC, caso de praças, parques (ecológicos, zoológicos, temáticos), bosques, grutas e outros, em geral o poder público mais local a este espaço gerenciará e definirá as metas de programa de maneira a contemplar ações efetivas de interpretação com vistas ao desenvolvimento de ações concretas de conservação junto ao público;

- em se tratando de espaços protegidos previstos no SNUC, para cada classe de unidades de conservação existem orientações para que o órgão gestor planeje o programa de EA. Em unidades de conservação de proteção integral com restrição máxima (caso das estações ecológicas e reservas biológicas) somente serão permitidas ações consideradas de EA enquanto que em unidades de menor restrição como os parques (nacionais, estaduais e municipais), monumentos naturais e refúgios da vida silvestre, a visitação e recreação são permitidas em áreas pré definidas. Já para as unidades de conservação de uso sustentável (florestas nacionais, estaduais e ou municipais, reservas extrativistas, áreas de relevante interesse ecológico, áreas de proteção ambiental, RPPN's, etc.) não há orientação específica para programas de EA. Em vários casos, inclusive, podem ser propriedades privadas (APA, ARIE e RPPN), seguindo interesses específicos.

- em se tratando de espaços privados protegidos ou não cada programa seguirá os interesses dos respectivos proprietários.

No que diz respeito à escolha do público, um diagnóstico da população já usuária e ou que possui interesse pelo uso dos espaços, é essencial para elaboração do programa. Variáveis como: origem, nível socioeconômico e cultural, nível de interesse e de frequência aos espaços (quando já existe o uso) auxiliarão na escolha das estratégias de melhoria da sensibilização, dos atributos mais representativos para a interpretação e identificação das responsabilidades de cada ator no processo e, por fim no desenvolvimento de ações concretas por parte deste público sobre estes espaços naturais.

Finalmente, há que se ter interesse político público e ou privado para que o programa se efetive e expanda no sentido de ações proativas de conservação para a área natural focada. 


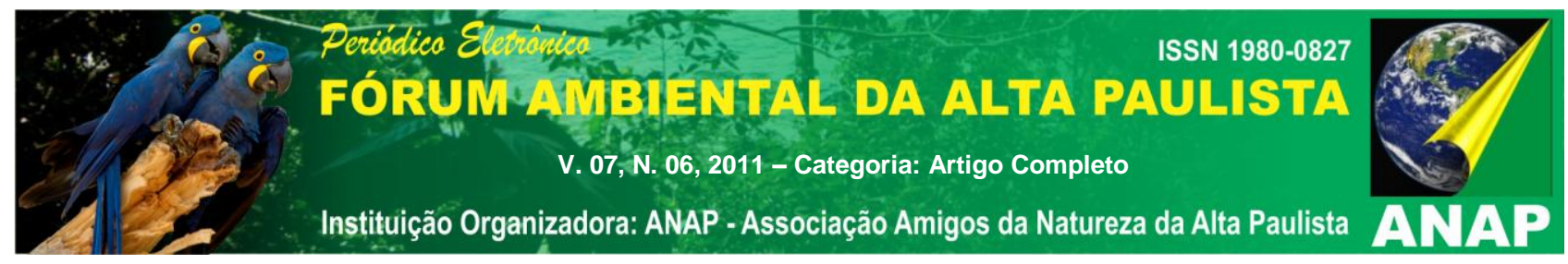

\section{CONCLUSÕES}

Diante do contexto apresentado, podemos nos perguntar qual o papel da educação ambiental diante de tantos impactos negativos que o planeta em sua totalidade vem sofrendo.

\section{Conforme Aziz Ab'Saber definiu:}

" a EA é um processo que envolve um vigoroso esforço de recuperação de realidades e que garante um compromisso com o futuro. Uma ação entre missionária e utópica destinada a reformular comportamentos humanos e recriar valores perdidos ou jamais alcançados. Trata-se de um novo ideário comportamental tanto no âmbito individual, quanto no âmbito coletivo."

Cremos que, o papel da educação ambiental deve ser o de difundir a esperança de que um novo mundo é possível. Mas essa esperança é qualificada. Trata-se de uma esperança crítica, ativa, não uma pura espera, uma espera vã, como dizia Paulo Freire (1992). Em suas palavras, "enquanto necessidade ontológica a esperança precisa da prática para tornar-se concretude histórica". Dessa forma, um mundo mais justo, equilibrado e com respeito a todas as formas de vida se torna uma utopia, ou seja, um sonho realizável.

\section{REFERÊNCIAL}

AB'SABER, A. A educação é a nova ponte entre a sabedoria popular e a consciência técnico-científica. Jornal o Educador Ambiental, n.1,1993.

BRASIL. Lei $n^{\circ}$ 9.795, de 27 de abril de 1999. Dispõe sobre a educação ambiental, institui a política nacional de educação ambiental e dá outras providências.

BRASIL. Lei $n^{\circ}$ 4.771, de 15 de setembro de 1965. Institui o novo Código Florestal.

CAVENAGHI, A. J. O território paulista na iconografia oitocentista: mapas, desenhos e fotografias. Análise de uma herança cotidiana. Anais do Museu Paulista: História e Cultura Material, v.14 n.1, 2006.

FREIRE, P. Pedagogia da Esperança: um reencontro com a pedagogia do oprimido. São Paulo: Paz e Terra, 1992. 


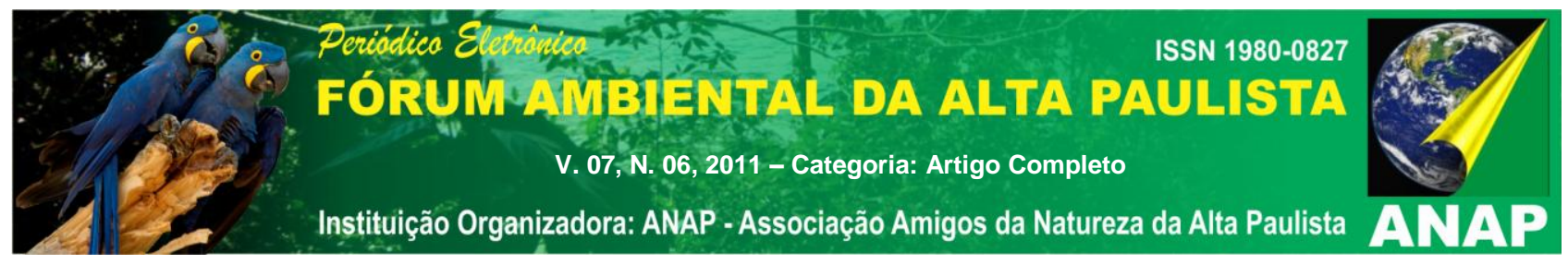

ITTELSON, W.H. Environmental Perception and Urban Experience. Environment and Behavior, v.10 n.2 p.193-213, 1978.

MEADOWS, D. H. Harvesting one Hundredfold - Key concepts and Case Studies in Environmental Education. United Nations Environment Programme UNEP/UNESCO, 1989.

MEDEIROS, R. Evolução das tipologias e categorias de áreas protegidas no Brasil. Ambiente \& Sociedade, v.4 n.1, 2006.

PARENTE, D. Tecnologia e violência sobre a natureza. 2008. In: Monjeau, A. (org.) Ecofilosofia. Ed. Fundação Boticário de Proteção à Natureza. Curitiba. 2008.

SÃO PAULO (ESTADO) - Conceitos para se fazer educação ambiental. Secretaria do Meio Ambiente do Estado de São Paulo, 1999.

SÃO PAULO (ESTADO) - Sistema Informações Florestais do Estado de São Paulo. Secretaria do Meio Ambiente do Estado de São Paulo. www.iflorestal.sp.gov.br/sifesp SATO. M. Educação Ambiental. $3^{\circ}$ ed. São Carlos: PPG-ERN/UFSCar, 1997.

SOUZA, A. C. A. A evolução da política ambiental no Brasil do século XX. Revista de Ciência Política, n.26, 2005. 